\title{
FLEKSIBILITAS HUKUM ISLAM DI MASA PANDEMI COVID-19
}

\section{ISLAMIC LAW FLEXIBILITY IN THE PANDEMIC OF COVID-19}

\author{
Rossa Ilma Silfiah ${ }^{1}$ \\ ${ }^{1}$ Ilmu Hukum, Fakultas Ilmu Sosial Politik, Universitas Yudharta Pasuruan \\ Jl. Pesantren Ngalah No. 7 Sengonagung, Purwosari, Pasuruan, Jawa Timur, 67161 \\ Email: rossasilfiah@gmail.com
}

\begin{abstract}
The Covid-19 pandemic has urged the issuance of PERPU No. 1 of 2020 in order to maintain the physical and spiritual health of individual citizens. Because after all, health is a primary need for individuals than others. This is in line with Maqashid Asy-syar'i which prioritizes the safety of the soul so that all worship activities and work activities are not hampered. The Covid 19 outbreak has changed the socio-political, economic, educational, cultural and defense structures of a nation. This research will find a correlation between the emergence of perpu with Islamic Law thoughts about Maqashid Asy-Syar'i. So that the implementation of the perpu can be accepted by Muslims. To determine this, a normative legal research method with a statutory approach is used. Of course, the concept of Islamic law is also a framework of argument in this research.
\end{abstract}

Keywords: Flexibility, Islamic law, pandemic

\section{Intisari}

Permasalahan yang terjadi dalam Pandemi Covid-19 ini bagi umat Islam yang diutamakan adalah terpeliharanya agama, artinya kegiatan beribadah dengan situasi apapun harus dilaksanakan. Maka Hukum Islam selalu hadir di tiap situasi apapun, agar umat Islam tetap tenang dalam menjalankan aktifitas agamanya. Dengan berbagai rujukan kesehatan tentang bahaya Covid-19 dan menjaga keamanan stabilitas negara dengan keluarnya perpu No. 1 Tahun 2020 yang saat ini menjadi Undang-undang, maka fatwa-fatwa ulama' yang tergabung dalam MUI maupun ormas keagamaan seperti Nahdlatul Ulama' telah memberikan solusi hukum yang cepat dan dan tepat. Inilah letak fleksibilitas Hukum Islam.

Kata Kunci: Fleksibilitas, hukum Islam, pandemi

\section{- Pendahuluan}

Indonesia merupakan bagian dari negara-negara di dunia yang eksistensinya juga dipengaruhi dengan hubungan internasional, tidak luput dari dampak Pandemi Covid-19. Sejak munculnya wabah ini Desember 2019 di Wuhan Cina, sampai sekarang Indonesia telah berupaya membentengi warga negaranya dari wabah ini. Berbagai kasus yang terjadi di negara-negara dunia, menjadi referensi bagi 
Pemerintah Indonesia untuk melangkah menentukan kebijakan. Presiden Jokowi sangat berhati-hati dengan kebijakan yang akan diambilnya, karena dampak dari kebijakan akan memengaruhi seluruh aspek kehidupan bangsa selanjutnya. Namun segala pertimbangan telah dilakukan, atas masukan dari Menkopolhukam Prof. Mahfudh MD dan pertimbangan dari berbagai unsur masyarakat. Akhirnya Peraturan Pemerintah Pengganti Undang-undang harus dikeluarkan untuk mengatasinya.

Pembentukan peraturan perundang-undangan pada umumnya meliputi tahapan perencanaan, penyusunan, pengesahan atau penetapan dan pengundangan. Perpu yang sejatinya dibentuk dalam Kegentingan yang Memaksa meniscayakan tahapan perencanaan tidak dilakukan, karena keadaannya bersifat tidak terduga, tidak terencana. Beberapa peraturan yang lainnya juga diperlukan untuk menindaklanjuti perpu tersebut, maka berbagai kajian holistik komprehensif dalam pengambilan keputusan secara cepat dan tepat.

AALF Van Dullemen dalam bukunya Staatsnoodrecht en Demicratic (1947), ${ }^{1}$ menyebut empat syarat hukum tata negara darurat yang sah:

1. Harus menjadi nyata bahwa kepentingan negara yang tertinggi menjadi taruhan ketika eksistensi negara tergantung pada dilakukannya tindakan darurat itu.

2. Tindakan itu sangat diperlukan dan tidak bisa diganti dengan tindakan lain.

3. Tindakan tersebut bersifat sementara (berlaku sekali) atau dalam waktu pendek untuk sekedar menormalkan kembali.

4. Ketika tindakan diambil, parlemen tak dapat bersidang secara nyata dan sungguh-sungguh.

Keempat syarat ini, menurut Dollemen harus terpenuhi semua. Jika salah satu syarat tidak ada, maka hukum darurat tidak boleh ada. Penetapan PERPU di Indonesia di atur dalam Pasal 22 Ayat 1 UUD NRI 1945: "Dalam hal ihwal kegentingan yang memaksa, Presiden berhak menetapkan peraturan pemerintah pengganti undang-undang". Hal ini juga tertulis dalam Pasal 1 angka 4 UndangUndang No. 12 Tahun 2011 tentang Pembentukan Peraturan Perundang-undangan yang berbunyi: "Peraturan Pemerintah Pengganti Undang-Undang adalah Peraturan Perundang-undangan yang ditetapkan oleh Presiden dalam hal ihwal kegentingan yang memaksa."

Berdasarkan bunyi kedua pasal di atas dapat kita ketahui bahwa syarat presiden mengeluarkan PERPU adalah dalam hal ihwal kegentingan yang memaksa. Dalam artikel berjudul Polemik Penolakan Perpu JPSK yang ditulis Yuli Harsono, dikatakan bahwa subyektivitas Presiden dalam menafsirkan "hal ihwal kegentingan yang memaksa" yang menjadi dasar diterbitkannya PERPU, akan dinilai DPR apakah kegentingan yang memaksa itu benar terjadi atau akan terjadi. Persetujuan DPR ini hendaknya dimaknai memberikan atau tidak memberikan persetujuan (menolak). Jadi, menurut Yuli Harsono, yang menafsirkan suatu kegentingan memaksa itu adalah dari subyektivitas Presiden. Inilah yang menjadi syarat ditetapkannya sebuah PERPU oleh Presiden. ${ }^{2}$

${ }^{1}$ Mahfud MD, 2011, Membangun Politik Hukum, Menegakkan Konstitusi, RajaGrafindo Persada, Jakarta, hlm. 108.

${ }^{2}$ https://www.hukumonline.com/klinik/detail/ulasan/lt5188b1b2dfbd2/syarat-syaratpenetapan-perpu-oleh-presiden/ 
Terlepas dari pembahasan Perpu No. 1 Tahun 2020, sebagian besar penduduk Indonesia yang menganut Agama Islam tentunya yang dipikirkan adalah persoalan agama, bagaimana harus menjalankan agamanya dengan sah sesuai standar protokoler WHO. Maka di sinilah yang menjadi fokus strategis bagi Hukum Islam sehingga selalu dinamis dalam menjawab persoalan secara fleksibel. Tampilan Hukum Islam yang fleksibel saat pandemi ini, bukanlah hal yang baru, akan tetapi sudah menjadi karakter bagi Hukum Islam yang rahmatan lil'aalamiin.

\section{- Pembahasan}

Situasi darurat Pandemi Covid-19 ini semakin dirasakan oleh masyarakat, karena pada dasarnya sudah ada aturan tentang karantina, sebagaimana dalam Undang-undang Nomor 6 Tahun 2018 tentang Kekarantinaan Kesehatan. Dan pengaruh dari karantina ini juga memengaruhi stabilitas ekonomi sebuah bangsa, maka situasi darurat ini telah dilegitimasi oleh Perpu No. 1 Tahun 2020 tentang Kebijakan Keuangan Negara dan Stabilitas Sistem Keuangan untuk Penanganan Pandemi Corona Virus Disease 2019 (COVID-19) dan/atau Dalam Rangka Menghadapi Ancaman yang Membahayakan Perekonomian Nasional dan/atau Stabilitas Sistem Keuangan, yang saat ini telah disetujui oleh DPR sebagai Undangundang, maka seluruh aktifitas kemasyarakatpun akan mengikuti prosedur yang telah ditetapkan negara. Termasuk dalam pembahasan ini yaitu tentang kegiatan keagamaan yang dilaksanakan secara bersama-sama.

Hukum Islam merupakan salah satu dari sumber hukum materiil (menurut penggolongan Algra), senada dengan cita-cita hukum masyarakat Indonesia sebagai nilai positif tertinggi dalam falsafah hidup masyarakat Indonesia. Sehingga Hukum Islam mewarnai falsafah hidup masyarakat Indonesia yaitu Pancasila yang dalam studi hukum dikenal dengan sumber dari segala sumber hukum dalam konteks kehidupan bermasyarakat, berbangsa dan bernegara di Indonesia.

Jika menengok sejarah lahirnya Pancasila sendiri merupakan hasil dari pemikiran-pemikiran oleh semua negarawan dan para ahli agama, termasuk juga para ahli hukum Islam.Sehingga dalam sila pertama dari Pancasila menyatakan "Ketuhanan Yang Maha Esa" hal ini sudah memberikan konsekuensi tersendiri bagi setiap umat beragama untuk beribadah kepada Tuhannya sesuai dengan agamanya masing-masing.

Fleksibilitas ialah sifat lentur dan dapat menyesuaikan dengan kondisi yang ada di sekitarnya. Fleksibilitas hukum Islam berarti kelenturan hukum Islam dalam menghadapi persoalan-persoalan yang muncul di tengah-tengah masyarakat. Kondisi masyarakat yang terus berkembang dan berubah menuntut hukum Islam untuk mampu menjawab berbagaipermasalahan-permasalahan yang timbul. Selain itu juga faktor kondisi dan adat kebiasaan masyarakat di setiap tempat tentunya pasti berbeda-beda. Hal ini menguji bagaimana sifat hukum Islam yang fleksibel mampu menyesuaikan dengan keadaan yang ada di sekitarnya.

Fleksibilitas ini nampaknya lebih banyak terdapat dalam persoalan-persoalan duniawi, seperti dalam persoalan teknis praktis dan seni yang lebih banyak menyangkut sarana dan metodenya. Hal inilah yang dikatakan Rasulullah Saw. dalam sabdanya, "kalian lebih mengetahui urusan dunia kalian sendiri". Begitu pula dengan para sahabat setelahnya. Mereka membuat peraturan-peraturan dan 
pekerjaan-pekerjaan yang tidak pernah ada di masa Rasulullah Saw., seperti membuat kantor-kantor, menentukan batas-batas wilayah, mengumpulkan AlQur'an dalam mushaf dan menyebarkannya ke seluruh wilayah, menunjuk orang khusus untuk jabatan qadhi, pengiriman pos, dan lain sebagainya yang banyak manfaatnya dan tidak diragukan lagi kemaslahatannya. Bahkan kemunculannya pun tidak pernah dihalangi oleh agama. ${ }^{3}$

Sifat fleksibel dari hukum Islam tersebut terbukti dengan dirumuskannya beberapa kaidah oleh ahli hukum Islam yaitu: al-hukmu yaduuru ma'a 'illatihi wujuudan wa 'adaman, artinya "Hukum berputar (berlaku) bersama ada atau tidak adanya 'illat". Maknanya adalah bahwa jika 'illah-nya ada, maka hukumnya pun ada. Sebaliknya, jika'illah-nya tidak ada, maka hukumnya pun tidak ada. Jika 'illah-nya kuat, maka hukumnya pun kuat. Sebaliknya, jika'illah-nya lemah, maka hukumnya pun lemah. Dalam Kaidah fiqhiyah lainnya juga menyebutkan: "Perubahan fatwa karena perubahan zaman, tempat, keadaan, niat dan kebiasaan".

Kaidah tersebut mengisyaratkan bahwa hal yang patut diperhatikan dari fatwa ialah faktor-faktor perubahan hukum itu sendiri, yaitu sesuai dengan perubahan zaman, tempat, keadaan, niat dan kebiasaan. Hal ini mengisyaratkan bahwa sejatinya hukum Islam itu bersifat fleksibel dalam menghadapi berbagai keadaan dan juga persoalan yang terjadi di masyarakat.

Bahkan jauh sebelum kaidah itu dibuat oleh para ahli hukum Islam, sifat hukum Islam yang fleksibel itu nampaknya telah ada pada masa Nabi dan Sahabat, dikisahkan bahwa ada seorang laki-laki yang bertanya kepada Nabi tentang bolehkan mencium istri ketika sedang berpuasa, pada waktu itu datang seorang pemuda, ia berkata, "Wahai Rasulullah, bolehkah saya mencium (istri) ketika sedang shaum?" Rasulullah menjawab, "Tidak". Kemudian datang orang tua, ia bertanya, "Bolehkah saya mencium (istri) ketika sedang shaum?" Rasulullah menjawab, "Ya". Orang yang diizinkan adalah orang tua, sedangkan orang yang dilarang adalah pemuda". Kemudian Nabi berkata "Sesungguhnya orang tua bisa menahan syahwatnya". ${ }^{4}$

Selanjutnya pada masa Abu Bakar, ia menetapkan hukuman peminum khamer sebanyak 40 kali cambukan, yang pada masa Rasulullah tidak ada batas tertentu, sampai Rasulullah berkata "cukup". Hal itu karena orang-orang yang minum khamer pada masa khilafah Abu Bakar lebih banyak daripada masa Nabi pada waktu itu.22 Kemudian pada masa Umar Bin Khattab, yaitu tidak diterapkannya hukuman potong tangan bagi pencuri dikarenakan kondisi paceklik, hal ini menunjukkan kedalaman ilmu Umar ra. yang hukumnya mengikuti perubahan keadaan dan kondisi masyarakat, yang dikenal dengan yaumul maja "ah "hari kelaparan", banyak orang yang mencuri karena keadaan terpaksa.

Hukum Islam yang fleksibel bisa dilihat dari karakternya yang Dinamis/harokah, sebagaimana dalam kaidah ushul fiqh menatakan: "tidaklah diingkari terjadinya perubahan hukum lantaran perubahan masa, tempat dan keadaan" (laa yunkaru taghayyurul ahkaam bi taghayyuril azmaan wal amkinah

\footnotetext{
3 Arif Fikri, Fleksibilitas Hukum Islam dalam Perubahan Sosial, http://ejournal.radenintan.ac.id

${ }^{4}$ Ibid, hlm. 152.
} 
wal ahwaal). Karena keberadaan Hukum Islam di tengah kehidupan manusia, ditujukan untuk kelestarian dan kemaslahatan manusia dan alam semesta. Hal ini tampak pada tujuan diberlakukannya Syari'ah (Maqashid al-Syar'i) dengan melindungi lima hal: melindungi agama (hifdzuddiin), melindungi jiwa (hifdzunnafs), melindungi akal (hifdzul'aql), melindungi keturunan (hifdzunasl), dan melindungi harta benda (hifdzulmaal). Pengertian melindungi agama, berkembang dari waktu ke waktu, apabila ditelusuri dari perspektif ibadah, maka perlindungan agama adalah meliputi kewajiban individu dalam menjaga ajaran agama Islam untuk diri sendiri. Menjaga dalam arti menjalankan semua kewajiban dalam Rukun Islam dan Rukun Iman setiap individu meskipun di tengah pandemi covid-19. Perlindungan jiwa dan raga menjadi sangat penting, karena terlaksananya ibadah dan aktifitas manusia yang lain akan terlaksana jika jiwa dan raga tetap sehat. Al-'aqlus saliim fil-jismis saliim, dalam akal yang sehat terdapat jiwa-raga yang sehat pula.

\section{Mashadir Asl-Syar'i (Sumber Hukum Islam)}

Dalam menaati hukum, Umat Islam mempunyai panduan yang jelas. Terkait Covid-19 ini tentunya dalam hal kesehatan, harus mematuhi anjuran dokter dan mematuhi aturan Pemerintah. Akan tetapi, dalam hal pelaksanaan ibadahnya mematuhi para Ulama'. Sebagaimana Hukum Islam mempunyai jenjang kredibilitas sumber hukum yang jelas, karena dalam penggalian hukum harus didasarkan pada Al-Qur'an dan Al-Hadits. Sebagaimana dalam Al-Qur'an ayat 59 Surat An-Nisa':

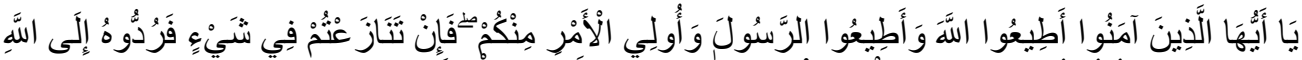

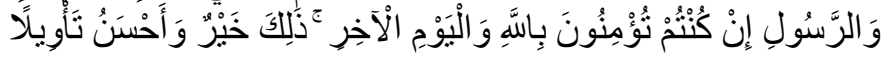

"Hai orang-orang yang beriman taatilah Allah dan Rasul-Nya dan orangorang yang memerintah dari golonganmu.Kalau kamu berbantah-bantahan tentang sesuatu (perkara), hendaklah kamu kembalikan kepada Allah dan Rasul, jika kamu beriman kepada Allah dan hari yang kemudian.Demikian itu yang lebih baik dan sebaik-baik jalan".

Lebih lanjut dalam praktek sahabat pernah terjadi dialog antara Rasulullah saw. dengan sahabat Muadz bin Jabal ra. Yang diutus oleh Rasul sebagai hakim (Qadli) di Yaman, adalah:

"Riwayat dari Mu'adz, sesungguhnya Rasulullah saw. mengutus Mu'adz bi Jabal untuk menjadikan qadli di Yaman,

- Rasul bertanya kepadanya, bagaimana sikapmu (Mu’adz) kalau ada suatu perkara yang dihadapkan kepadamu?

- Jawab Mu'adz: akan saya selesaikan dengan Kitab Allah (ayat-ayat AlQur'an).

- Rasul bertanya lagi: Kalau engkau tidak menemukannya di dalam Kitab Allah?

- Mu'adz menjawab: akan saya selesaikan dengan Sunnah Rasul-Nya 
- Rasul bertanya lagi: Kalau engkau tidak menemukannya dalam Sunnah?

- Jawab Mu'adz: Saya akan berijtihad

Kemudian Rasulullah menepuk dadanya sambil berkata segala puji bagi Allah yang memberi taufiq kepada utusan Rasulullah yang diridlaiNya."(H.R. Abu Dawud)

Apabila kaidah-kaidah hukum tersebut dibentuk menurut cara-cara yang telah ditetapkan, sebagaimana pada teori $W$. Zevenbergen. Menurut paham positifistik, hukum akan berlaku jika melalui proses pembentukan hukum yang benar, yaitu dibuat oleh lembaga yang berwenang. Dalam Hukum Islam dikenal dengan Ijtihad, dimana seorang Mujtahid dalam penggalian hukum (istinbath) harus memenuhi prosedur dan persyaratan tertentu. Adapun jenjang sumber hukum dalam Islam, yaitu:

1. Al-Qur'an,

Al-Qur'an berasal dari kata qara'a. Kata Al-Qur'an berbentuk masdar dengan arti ism maf'ul (dibaca). Di dalam Al-Qur'an sendiri ada pemakaian kata "Qur'an" dalam arti demikian sebagai tersebut dalam ayat 17 dan 18 Surat A1Qiyamah. Kemudian dipakai kata "Qur'an" itu untuk Al-Qur'an yang dikenal sekarang ini adapun definisinya Al-Qur'an ialah: "Kalam Allah SWT yang merupakan mu'jizat yang diturunkan (diwahyukan) kepada rasul dan yang ditulis di mushaf dan diriwayatkan dengan mutawatir serta membacanya adalah ibadah". Dengan definisi ini, kalam Allah yang diturunkan kepada nabi-nabi selain nabi Muhammad SAW tidak dinamakan Al-Qur'an seperti Taurat yang diturunkan kepada Nabi Musa as atau Injil yang diturunkan kepada Nabi Isa as. Dengan demikian, Kalam Allah yang diturunkan kepada Nabi Muhammad saw yang membacanya tidak dianggap ibadah, seperti Hadits Qudsi, tidak pula dinamakan Al-Qur'an. ${ }^{5}$

2. As-Sunnah,

Sunnah adalah perkataan-perkataan Nabi Muhammad saw, perbuatanperbuatan nabi dan taqrir-taqrirnya atau apa yang dinuklilkan dari Nabi Muhammad saw. baik perkataan, perbuatan, maupun taqrir. Asy-Syathibi menerangkan bahwa "As-Sunnah" dipakai menjadi nama bagi segala yang dinukilkan dari Nabi SAW, baik menjadi penerangan bagi isi Al-Qur'an, ataupun tidak. Ringkasnya sunnah itu sebutan bagi sabda nabi, perbuatan nabi, taqrir nabi. Taqrir merupakan penetapan nabi dengan cara berdiam diri, tidak membantah dan menegur terhadap sesuatu pekerjaan yang dikerjakan seorang shahabat. ${ }^{6}$ Hal ini ditunjukkan oleh hadist: "Peganglah olehmu sekuat-kuatnya akan sunnahku dan sunnah khulafaur rasyidin sesudahku" (H.R. Abu Daud).

3. Ijma'

Menurut Abdul Wahab Khallaf, ijma' adalah kesepakatan seluruh mujtahid pada suatu masa setelah wafatnya Nabi Muhammad SAW terhadap suatu hukum syara' mengenai permasalahan hukum. Ahmad Hasan juga menyebutkan beberapa definisi ijma' dengan mengatakan bahwa 'kesepakatan

5 Yayasan Penterjemah/Pentafsir Al-Qur'an, Al-Qur'an dan Terjemahnya, (Madinah Munawwarah: Mujma' al-Malik Fahd Li Thiba'at al-Mushhaf Asy-Syarif), hlm. 15

${ }^{6}$ Hasbi Ash-Shiddieqy, 1994, Pengantar Hukum Islam, Jakarta: Bulan Bintang, hlm. 193 
umat Islam dalam menangani masalah agama”. Ijma' juga bisa bermakna "kesepakatan bulat para ahli hukum pada masa tertentu dalam menjawab masalah-masalah tertentu". ${ }^{7}$ Termasuk bagian dari ijma' adalah fatwa MUI maupun NU dan Muhammadiyah yang dijadikan pegangan oleh pengikutnya untuk tetap beribadah di saat Pandemi Covid-19 ini.

\section{Maqashid Al-Syar'i (Tujuan Hukum Islam)}

Maqashid al-Syar'i pertama kali dikemukakan oleh Imam Turmudzi (wafat 296 H/908 M) dalam kitab ash-shalah wa maqashiduha. Kitab ini mengurai sekumpulan hikmah dan rahasia spiritual di balik setiap gerakan shalat. Menegaskan ketundukan sebagai maqashid/tujuan di balik pengagungan kepada Allah SWT melalui setiap gerakan shalat. Mencapai kesadaran sebagai tujuan di balik memuji Allah SWT. Menfokuskan shalat seseorang sebagai tujuan menghadap Ka'bah sebagai kiblat. Berikutnya teori maqashid dikemukakan oleh Abu Zaid al-Balkhi dalam Kitab al-ibanah ilal ad-diyanah (menjelaskan tujuantujuan di balik praktik ibadah) dan Kitab Mashalih al-abdan wal anfus (kemaslahatan-kemaslahtaan raga dan jiwa). ${ }^{8}$

Maqashid Al-Syar'i yaitu sasaran, tujuan atau maksud dibalik hukum, bagi sejumlah teoritikus Hukum Islam sebagai pernyataan alternatif untuk kemaslahatan-kemaslahatan. Misalnya Abdul Malik Al-Juwaini (W. 478 H / 1185 M) salah seorang kontributor yang paling awal menggunakan istilah al-maqashid dan al-mashalih al-'ammah (kemaslahatan-kemaslahatan umum). Imam AlGhazali (W. 505 H / 1111 M) mengelaborasi klasifikasi maqashid yang ia masukkan dalam kategori mashlahah mursalah (kemaslahatan yang tidak disebut secara langsung dalam nas Al-Qur'an dan Hadits. Najmuddin Ath-Thufi (W. 716 $\mathrm{H} / 1216 \mathrm{M}$ ) adalah tokoh yang memberikan hak istimewa pada kemaslahatan, dengan pernyataannya "Suatu maksud tidak sah, kecuali jika mengantarkan pada pemenuhan kemaslahatan atau menghindari kemudlaratan".

Teori ini berkembang lagi dengan berbagai penyempurnaan dan menyeluruh oleh al-Syathiby pada $790 \mathrm{H} / 1400 \mathrm{M}$. Melalui karya gemilangnya kitab almuwafaqat, maqaashid asy-syar'i menjadi konsep baku dalam Ilmu Ushul Fiqh. Sebelum teori maqaashid asy-syar' $i$, metode penalaran terhadap nash terdapat dua teori, yaitu: teori keumuman lafadz ('umuum al-lafdz) dan teori kekhususan sebab (khushush al-sabab). ${ }^{10}$ Teori ini sangat penting dipergunakan dalam negara hukum, mengingat teori ini sangat bersinggungan dengan nilai humanisme, genetika, agama, sosial dan ekonomi. Tujuan diberlakukannya hukum harus mempertimbangkan:

1. Maqashid al-Dlaruriyat (tujuan primer), dimaksudkan untuk memelihara lima unsur pokok dalam kehidupan manusia. Yaitu: menjaga agama (hifdz al-diin),

${ }^{7}$ Moh. Dahlan, Paradigma Ushul Fiqh Multikultural Gus Dur, IAIN Bengkulu, 2013, hlm.

8 Jasser Audah, Penerjemah Rasidin dan Ali Abd. Mun'im, 2015, Membumikan Hukum Islam melalui Maqashid Al-Syar'i, hlm. 46

${ }^{9}$ Ibid., hlm. 33.

${ }^{10}$ Asafri Jaya Bakri, 1996, Konsep Maqashid Syari'ah, Jakarta: Rajawali Pers, Jakarta), .hal. 
menjaga jiwa (hifdz al-nafs), menjaga akal (hifdz al-'aql), menjaga keturunan (hifdz al-nasl) dan menjaga harta (hifdz al-maal).

2. Maqashid al-Hajiyat (tujuan sekunder), dimaksudkan untuk menghilangkan kesulitan lima unsur pokok dalam kehidupan manusia

3. Maqashid al-Tahsiniyat (tujuan tersier), dimaksudkan agar manusia dapat melakukan yang terbaik untuk penyempurnaan pemeliharaan lima unsur pokok dalam kehidupan manusia

Segi menolak kemudlaratan dan menghindari kerusakan, syari'at mengadakan macam-macam hukuman pidana bagi orang yang melakukannya. Untuk menolak kemudlaratan dan kehancuran agama, Hukum Pidana Islam menetapkan dan mewajibkan jihad ${ }^{11}$ terhadap orang yang menghambat dakwah Islamiyah, menghukum pembuat bid'ah dan sebagainya.

Diadakannya hukum qishash dan kafarat bagi orang yang dengan sengaja melakukan tindak makar, pembunuhan dan diharamkannya bunuh diri merupakan bentuk usaha untuk menghindarkan kemudlaratan bagi jiwa. Untuk menolak kemudlaratan akal, Hukum Pidana Islam memberikan hukuman bagi peminum khamr. Perbuatan zina juga dilarang dalam dan diberikan sanksi had bagi pelakunya, hal ini dimaksudkan untuk menghindarkan dari kemudlaratan bagi berlangsungnya keturunan. Untuk menghindari kemudlaratan harta, Hukum Pidana Islam memberikan ancaman potong tangan kepada siapa yang mencuru, mengharamkan riba. ${ }^{12}$

Bahasan utama dalam teori ini adalah mengenai masalah hikmah dan illat ditetapkannya sebuah hukum. ${ }^{13}$ Sehingga dengan demikian akan diketahui bagaimana hakikat dan tujuan awal pemberlakuan hukum yaitu kemashlahatan manusia. Kemashlahatan itu akan terwujud apabila kelima unsur pokok (agama, jiwa akal, keturunan dan harta) terpelihara:

1. Memelihara agama

2. Memelihara Jiwa

3. Memelihara Akal

4. Memelihara Keturunan

5. Memelihara Harta

Dalam usaha memelihara lima unsur pokok itu, al-Syathibi membagi tiga tingkat: ${ }^{14}$

1. Maqashid al-Dlaruriyat (tujuan primer), dimaksudkan untuk memelihara lima unsur pokok dalam kehidupan manusia.

2. Maqashid al-Hajiyat (tujuan sekunder), dimaksudkan untuk menghilangkan kesulitan lima unsur pokok dalam kehidupan manusia

11 Pengertian jihad dalam hlm ini tidak dimaksudkan untuk berbuat anarki, karena bila dihubungkan dengan Surat Al-An'am ayat 108, jelas sekali perbuatan menghina kepercayaan, ajaran agama lain tidak dibenarkan dalam Islam.

${ }^{12}$ Mukhtar Yahya, Fathurrahman, Dasar-dasar Pembinaan Hukum Fiqh Islami, Bandung: Al-Ma'arif, 1993, hlm. 334-335.

${ }^{13}$ Ahmad al-Raisuni, Nadzariyat al-Maqashid 'Inda al-Syathibi, Dar al-Yaman, Rabath, 1991, hlm. 67.

${ }^{14}$ Asafari, Op Cit., hlm. 71-72. 
3. Maqashid al-Tahsiniyat (tujuan tersier), dimaksudkan agar manusia dapat melakukan yang terbaik untuk penyempurnaan pemeliharaan lima unsur pokok dalam kehidupan manusia.

Permasalahan yang terjadi dalam Pandemi Covid-19 ini bagi umat Islam yang diutamakan adalah terpeliharanya agama, artinya kegiatan beribadah dengan situasi apapun harus dilaksanakan. Maka Hukum Islam selalu hadir di tiap situasi apapun, agar umat Islam tetap tenang dalam menjalankan aktifitas agamanya. Dengan berbagai rujukan kesehatan tentang bahaya Covid-19 dan menjaga keamanan stabilitas negara dengan keluarnya perpu No. 1 Tahun 2020 yang saat ini menjadi Undang-undang, maka fatwa-fatwa ulama' yang tergabung dalam MUI maupun ormas keagamaan seperti Nahdlatul Ulama' telah memberikan solusi hukum yang cepat dan dan tepat. Inilah letak fleksibilitas Hukum Islam.

Secara garis besar, kebijakan hukum atau pembaruan hukum dalam Islam sangat mempertimbangkan kemashlahatan umat/masyarakat. Kaidah ushul fiqih menyatakan bahwa tasharruful imaam 'alarra'iyyah manuthun bil-mashlahah, yang berarti kebijakan pemimpin atas rakyatnya harus mempertimbangkan kemashlahatan masyarakat secara luas. Kemaslahatan dalam hal ini mencakup kesejahteraan rakyat, dan kesejahteraan rakyat akan tercapai dengan cara menghilangkan kemudlaratan/kerusakan. Hal ini bisa dipelajari dari contoh di masa Nabi saw, pernah menegur seorang sahabat karena membiarkan ontanya tidak tertambat dengan dalih tawakal kepada Allah SWT, sementara ia masuk masjid hendak shalat. Hadits lain juga secara jelas mengatur lockdown ketika terjadi wabah tha'un; "Jika kalian mendengar kabar tentang merebaknya wabah tha'un di sebuah wilayah, janganlah kamu memasukinya. Dan jika kalian tengah berada di dalamnya, maka janganlah kamu keluar darinya. (HR. Bukhari dan Muslim).

Nabi saw pernah menganjurkan tinggal di rumah daripada ke masjid hanya karena hujan lebatmenakutkan. Nabi saw juga pernah berujar agar yang sakit tidak bercampur dengan yang sehat (HR. Bukhari dan Muslim). Rasa takut dan sakit diyakini sebagai udzur (alasan) untuk tidak shalat berjamaah di masjid. Contohcontoh ini merupakan preseden yang baik untuk diteladani saat pandemi ini. Fikih pada dasarnya telah memberi ruang fleksibilitas yang sangat terbuka, saat bahaya mengintai dan juga membahayakan orang lain, maka semua ibadah tidak bisa dilakukan secara normal. Jika tidak mampu berdiri untuk shalat, maka dengan duduk, jika duduk tak mampu dilakukan, maka dengan berbaring dan seterusnya.

\section{Pengertian Syari'ah dan Fiqih}

Syari'ah berasal dari syara'a yasyra'u syar'an syarii'atan, yang berarti tempat memancarnya air/mata air, jalan menuju air, jalan/cara/metode/ sistem dalam agama. Al-Qurthubi mengartikan sesuatu yang ditetapkan Allah untuk hamba-hamba-Nya dalam bentuk sebuah agama. ${ }^{15}$ Salam Madkur mendefinisikan: segala sesuatu yang digariskan Allah untuk hamba-hamba-Nya meliputi Aqidah, hukum, dan etika, dengan tujuan untuk mencapai kebahagiaan dunia akhirat sekaligus. Muhammad Yusuf Musa mengartikan: semua ketentuan agama yang

${ }^{15}$ Ahmad Sukardja, Mujar ibnu Syarif, 2012, Tiga Kategori Hukum, Jakarta: Sinar Grafika, hal. 54 
telah ditetapkan Allah untuk umat Islam, sebagaimana yang termaktub dalam AlQur'an maupun Sunnah Nabi saw.

Fiqh dari segi bahasa adalah bentuk mashdar dari faqiha yafqahu fiqhan, yang berarti pemahaman yang mendalam dan akurat sehingga dapat dipahami (dengan baik) tujuan ucapan dan atau tindakan (tertentu). Kata Fiqih sinonim dengan al'ilm artinya pengetahuan dan al-fahm artinya pemahaman. Abdul Wahab Khallaf mendefinisikan fiqih yaitu: ilmu tentang hukum-hukum syara' yang bersifat perbuatan (yang dipahami) dari dalil-dalilnya yang rinci. Kalau hukum syara' yang berkaitan dengan keyakinan disebut ilmu kalam (Aqidah). Perbedaan Fiqih dengan Syari'ah yaitu: ${ }^{16}$

\section{Tabel 1}

\section{Perbedaan Syari'ah dan Fiqh}

\begin{tabular}{|l|l|}
\hline Syari'ah & Fiqih \\
\hline $\begin{array}{l}\text { Kebenaran Mutlak karena } \\
\text { bersumber dari Wahyu Allah } \\
\text { melalui Nabi Muhammad saw } \\
\text { (yang tidak melalui Nabi } \\
\text { Muhammad saw bukan Syari'ah) }\end{array}$ & $\begin{array}{l}\text { Kebenaran nisbi atau relatif, } \\
\text { karena bersumber dari Madzhab }\end{array}$ \\
\hline $\begin{array}{l}\text { Terjaga sehingga terhindar dari } \\
\text { penggantian dan perubahan }\end{array}$ & $\begin{array}{l}\text { Terbuka peluang terjadinya } \\
\text { perbedaan pendapat }\end{array}$ \\
\hline $\begin{array}{l}\text { Diterapkan di segala zaman dan } \\
\text { tempat }\end{array}$ & $\begin{array}{l}\text { Elastis dan dinamis sesuai tempat, } \\
\text { waktu maupun keadaan }\end{array}$ \\
\hline
\end{tabular}

Demikianlah penjelasan tentang Hukum Islam yang terdiri dari Syari'ah dan Fiqih, sehingga Hukum Islam selalu tampil fleksibel dan dinamis dikarenakan Fiqih membuka peluang ijtihad sesuai dengan manhaj (metode) madzhab fiqih. Sehingga mampu menjawab persoalan-persoalan ibadah maupun persoalan-persoalan berbangsa dan bernegara. Adapun hal-hal yang terkait Covid-19 ini, kita bisa menjumpai beberapa fatwa MUI maupun ormas keagamaan antara lain:

a. Mengganti Shalat Jum'at dengan Shalat Dhuhur di rumah

Shalat Jum'at merupakan kewajiban bagi umat Islam, fardlu 'ain bagi laki-laki balligh, berakal, sehat (tidak sakit atau tidak terhalang udzur), muqim (bukan dalam perjalanan. Namun ketika terjadi Wabah Covid-19 yang penularannya sangat cepat ketika ada kerumunan orang, maka kewajiban itupun menjadi haram hukumnya, apabila sedang sakit. Sebagaimana Hadits Nabi saw: "Janganlah yang sakit bercampur-baur dengan yang sehat"(HR. Bukhari Muslim $)^{17}$

b. Meninggalkan Shalat Jum'at berkali-kali

Hadits Nabi saw: "Siapa yang meninggalkan Shalat Jum'at tiga kali tanpa udzur, niscaya ia tergolong orang munafiq". Jadi kalau meninggalkan Shalat

${ }^{16}$ Ibid., hlm. 68.

${ }^{17}$ Faried F. Saenong, dkk, 2020, Fikih Pandemi: Beribadah di masa wabah, Jakarta: Nuo Publishing, hlm., 15. 
Jum'at dengan meremehkan dan tanpa udzur, maka haram hukumnya. Namun, merebaknya Wabah Covid-19 ini, maka keadaan ini masuk kategori Udzur. Beberapa udzur yang membolehkan tidak shalat jum'at antara lain: hujan lebat yang sekiranya dapat membasahi pakaiannya dan menyebabkan sakit, kekhawatiran adanya keselamatan jiwa, kehormatan diri dan keamanan harta bendanya. ${ }^{18}$

c. Barisan Shalat berjarak 1 meter

Ulama' Madzhab Hanafi, Maliki, Syafi'i dan Hambali menyatakan hukum taswiyah shufuf adalah mustahab (tidak wajib), sehingga meninggalkan kerapian shaf (barisan shalat) tidak membatalkan shalat. ${ }^{19}$ Maka melaksanakan shalat berjama'ah dengan jarak 1 meter hukumnya adalah tetap sah shalatnya. Karena menjaga keselamatan dan kesehatan merupakan tujuan yang tidak boleh diabaikan dalam Islam.

d. Menutup masjid untuk pendatang.

Hadits Nabi saw: "Jika kalian mendengar kabar tentang merebaknya wabah tha'un di sebuah wilayah, janganlah kamu memasukinya. Dan jika kalian tengah berada di dalamnya, maka janganlah kamu keluar darinya. (HR. Bukhari dan Muslim). Hadits ini menjadi pegangan warga masyarakat bahkan pemerintah dalam memutuskan kebijakan Lockdown atau PSBB (Pembatasan Sosial Berskala Besar) bagi daerah yang tergolong Zona Merah Covid-19. ${ }^{20}$ Maka sudah maklum, jika di masjid-masjid terutama yang terletak di jalan raya, ditulis "SELAIN WARGA TIDAK DIPERKENANKAN MASUK MASJID". Hal-hal seperti ini pada akhirnya menjadi maklum diberlakukan di masjidmasjid yang sebenarnya tidak ada diskriminasi untuk memasukinya (asal beragama Islam). Bahkan sejumlah negara atas himbauan ulama' setempat menutup masjid demi kesehatan warga masyarakatnya. Hal ini bukan untuk merendahkan agama dan rumah Allah SWT, apalagi muncul stigma bahwa masjid sebagai tempat penyebaran virus, karena jama'ahnya sudah berwudlu', bersih dan suci. Masalah utamanya adalah mencegak berkumpulnya banyak orang untuk menghindari kontak fisik di masa pandemi. Hadits Nabi saw: "Hindarilah wabah penyakit, seperti larimu (menghindari) kejaran macan". (HR. Bukhari Muslim) ${ }^{21}$

Merujuk pada sejarah, Masjidil Haram pernah ditutup pada tahun $827 \mathrm{H}$. Akibat wabah yang melanda Mekkah dan menelan korban jiwa sebanyak 1.700 orang. Ibnu Hajar Al-Asqalani juga mencatat peristiwa merebaknya wabah Tha'un di Damaskus pada Tahun $749 \mathrm{H}$ yang mengkritisi praktik warga dan pemuka masyarakat yang berkumpul untuk melaksanakan doa bersama, dan warga terjangkiti semakin meningkat tajam. ${ }^{22}$

e. Mengenakan masker saat shalat

Imam Nawawi dalam al-Majmu' menyatakan makruh menggunakan litsam (masker) dengan dalil bahwa "Rasulullah saw melarang seseorang shalat

\footnotetext{
${ }^{18}$ Ibid., hlm., 17.

${ }^{19}$ Ibid., hlm., 22.

${ }^{20} \mathrm{Ibid}$, hlm., 22.

${ }^{21}$ Ibid., hlm., 18.

${ }^{22}$ Ibid., hlm. 25.
} 
dengan menutup mulut”. (HR, Abu Dawud). Situasi pandemi Covid-19 yang penularannya melalui mulut dan hidung, sedangkan tidak bisa dipastikan, apakah tempat sujud telah steril dari virus, maka dibolehkan memakai masker karena darurat. Karena prinsip dari kaidah fiqhiyah menolak madlarat lebih diutamakan daripada mengambil manfaat. Akan tetapi, lebih diutamakan tidak memakai masker, tapi dengan membawa sajadah sendiri dari rumah. Apalagi jika bisa dipastikan bahwa tempat sujud telah steril, maka tidak dianjurkan memakai masker.

f. Menggunakan Hand Sanitizer

Hand sanitizer terbuat dari bahan aktif alkohol yang di kalagan ulama' menyatakan bahwa alkohol hukumnya najis, termasuk wewangian. Imam AsySyaukani salah satu yang menyatakan bukan najis. Fatwa MUI tahun 2009 menyatakan bahwa pada prinsipnya hukum alkohol tergantung pada proses pembuatannya. Jika dibuat atau dihasilkan dari bahan najis, maka hukumnya haram digunakan, terutama saat shalat. Jika terbuat dari bahan yang bukan najis, maka boleh digunakan. Atas dasar itu, maka boleh menggunakan hand sanitizer, apalagi jika sulit menemukan air untuk membasuh. ${ }^{23}$

g. Mengurangi syi'ar Ramadlan

Shalat Tarawih dan bedug sahur, sangat ditunggu-tunggu Umat Islam di Indonesia. Semarak Ramadlan membawa berkah tersendiri bagi perekonomian warga terutama saat ngabuburit. Namun, pada Ramadlan 2020 ini, suasana tersebut nyaris hilang. Shalat Tarawih yang biasanya dilaksanakan berjama'ah di Masjid maupun pondok pesantren, juga dikurangi jumlah jama'ahnya, karena harus berjarak 1 meter. Shalat Tarawihpun boleh dikerjakan jama'ah di rumah. Berbuka bersama dengan komunitas juga tidak diperbolehkan, karena khawatir kerumunan.

h. Shalat Ied di rumah

Majelis Ulama Indonesia ( MUI) menerbitkan fatwa tentang panduan kaifiat takbir dan shalat Idul Fitri saat pandemi Covid-19. Fatwa itu diterbitkan pada Rabu 13 Mei 2020. Dalam fatwa tersebut, MUI menyebutkan bahwa shalat Idul Fitri boleh dilaksanakan di rumah jika seseorang berada di kawasan dengan penyebaran Covid-19 yang belum terkendali. "Shalat Idul Fitri boleh dilaksanakan di rumah dengan berjamaah bersama anggota keluarga atau secara sendiri, terutama jika ia berada di kawasan penyebaran Covid-19 yang belum terkendali," demikian bunyi petikan fatwa Nomor 28 Tahun 2020 itu.

Sementara itu, jika umat Islam berada di kawasan dengan tingkat penularan Covid-19 yang sudah terkendali, shalat Idul Fitri dapat dilaksanakan secara berjemaah di masjid, mushala, tanah lapang, atau tempat lainnya. Pelaksanaan shalat Idul fitri, baik di masjid maupun di rumah, harus menerapkan protokol kesehatan dan mencegah terjadinya potensi penularan Covid-19. ${ }^{24}$ Pertimbangannya;

1. Shalat Idul Fitri hukumnya sunnah muakkadah yang menjadi salah satu syi'ar keagamaan (syi'ar min sya'air al-Islam).

${ }^{23}$ Ibid., hlm. 29.

${ }^{24}$ https://nasional.kompas.com/read/2020/05/14/05492171/mui-terbitkan-fatwa-soalshalat-idul-fitri-boleh-dilaksanakan-di-rumah 
2. Shalat idul fitri disunnahkan bagi setiap Muslim, baik laki-laki maupun perempuan, merdeka maupun hamba sahaya, dewasa maupun anak-anak, sedang di kediaman maupun sedang bepergian (musafir), secara berjamaah maupun secara sendiri.

3. Shalat Idul fitri sangat disunahkan untuk dilaksanakan secara berjamaaah di tanah lapang, masjid, mushala, dan tempat lainnya

4. Shalat Idul Fitri berjamaah boleh dilaksanakan di rumah.

5. Pada malam Idul Fitri, umat Islam disunahkan untuk menghidupkan malam Idul Fitri dengan takbir, tahmid, tasbih, serta aktivitas ibadah.

Adapun ketentuan shalat Idul Fitri di kawasan Covid-19 menurut MUI adalah;

1. Jika umat Islam berada di kawasan Covid-19 yang sudah terkendali pada saat 1 Syawal $1441 \mathrm{H}$, yang salah satunya ditandai dengan angka penularan menunjukkan kecenderungan menurun dan kebijakan pelonggaran aktivitas sosial yang memungkinkan terjadinya kerumunan berdasarkan ahli yang kredibel dan amanah, shalat Idul Fitri dilaksanakan dengan cara berjamaah di tanah lapang, masjid, mushala, atau tempat lain.

2. Jika umat Islam berada di kawasan terkendali atau kawasan yang bebas Covid19 dan diyakini tidak terdapat penularan (seperti di kawasan pedesaan atau perumahan terbatas yang homogen, tidak ada yang terkena Covid-19, dan tidak ada keluar masuk orang), shalat Idul Fitri dapat dilaksanakan dengan cara berjamaah di tanah lapang/masjid/ mushala/ tempat lain.

3. Shalat Idul Fitri boleh dilaksanakan di rumah dengan berjamaah bersama anggota keluarga atau secara sendiri (munfarid), terutama jika ia berada di kawasan penyebaran Covid-19 yang belum terkendali. Jumlah jamaah yang shalat minimal 4 orang yang terdiri dari 1 orang imam dan 3 orang makmum.

4. Pelaksanaan shalat Idul Fitri, baik di masjid maupun di rumah, harus tetap melaksanakan protokol kesehatan dan mencegah terjadinya potensi penularan.

Wabah virus corona yang merebak membuat hampir seluruh negara di dunia membatasi perjalanan masuk dan keluar, untuk mencegah penularannya. Termasuk tanah suci Mekah di Arab Saudi. Pemerintah setempat sudah membatasi masuknya jamaah sejak Februari 2020 lalu. Pembatasan ini belum diketahui akan berlaku hingga kapan. Bahkan, pada tanggal 05 Maret 2020, kerajaan Arab Saudi juga menutup berkala masjidil haram setelah salat Isya hingga jelang salat Subuh setiap harinya. Sementara itu, bagi penduduk Arab Saudi dan warga yang menetap di sana, dilarang mendatangi Masjid Nabawi dan Masjidil Haram untuk sementara.

Keputusan Kementerian Agama RI Nomor 494 Tahun 2020 tentang Pembatalan Haji 2020 telah dikeluarkan. Keputusan tersebut diambil mengingat pandemi Covid-19 masih melanda hampir seluruh belahan dunia, termasuk Indonesia dan Arab Saudi. "Pihak Arab Saudi tak kunjung membuka akses bagi jemaah haji dari negara mana pun. Akibatnya, pemerintah tidak mungkin lagi memiliki cukup waktu untuk melakukan persiapan, utamanya dalam pelayanan dan perlindungan jemaah, hal ini disampaikan Menteri Agama Fachrul Razi dalam konferensi pers secara virtual, pada hari Selasa 2 Juni $2020 .{ }^{25}$ Tentunya keputusan

\footnotetext{
${ }^{25}$ https://nasional.kompas.com/read/2020/06/02/10520421/pemerintah-batalkanpemberangkatan-jemaah-haji-2020.
} 
ini berdampak besar terhadap 221.000 Calon Jama'ah Haji asal Indonesia, karena keberangkatan untuk beribadah Rukun Islam yang kelima ini sudah ditunggutunggu sejak lama. Keputusan ini bukanlah keputusan yang gegabah, karena perlindungan negara terhadap warga negaranya meliputi keselamatan jiwa raganya saat menjalankan ibadah di Tanah Suci.

Kakanwil Kemenag Jatim, Dr H Ahmad Zayadi MPd., menyatakan, jika haji 2020 ini dipaksakan terlaksana, maka pelaksanaannya mencapai 3 bulan. Mengapa bisa tiga bulan? Karena semua jemaah harus mengikuti protokol kesehatan wabah corona. Saat tiba di Asrama Haji, karantina 14 hari. Tiba di Saudi, karantina 14 hari. Lalu pulangnya harus karantina 14 hari. Ditambah durasi ibadah sebanyak 42 hari. Maka total nencapai 82 hari atau hampir 3 bulan. Risiko kesehatannya juga sangat tinggi, karena pada umumnya Jamaah haji Indonesia seringkali memilih tempat dan waktu yang afdol. Apa mungkin mereka tidak berdesa ${ }^{26}$ kan saat tawaf, di Arafah dan lempar jumrah.

Dikutip dari The New Arab yang mengambil dari Saudi King Abdul Aziz Foundation for Research and Archives, telah terjadi sekitar 40 kali pembatalan haji. Ada beberapa penyebabnya sehingga ibadah haji yang rutin dilaksanakan pada bulan Dzulhidjah itu dibatalkan. Misalnya, konflik bersenjata juga wabah penyakit. Antara lain, yaitu: ${ }^{27}$

1. Serangan Qarmatin

Pembatalan haji sempat terjadi pada tahun 930 Masehi akibat pemberontakan Suku Qarmatian yang berbasis di Arab Timur. Di wilayah yang kini dikenal sebagai Bahrain ini, suku pimpinan Abu Tahir Al-Jannabi menyerang para muslim dengan sadis. Pemberontakan Qarmatian adalah insiden yang sangat penting dan besar dalam sejarah Islam. Pemimpin pemberontakan tidak hanya menyerang Makkah yang mengakibatkan penundaan haji serta ibadah lain, tapi juga simbol Islam yang sangat suci," kata tokoh dan imam Umar Al-Qadri di Islamic Centre of Ireland, Dublin.

Kelompok tersebut menjarah Hajar Al-Aswad dan potongan-potongannya serta menodai sumur zam-zam. Sumur yang dekat dengan Kakbah ini menjadi lokasi pembuangan mayat jamaah haji yang dibunuh. Batu Hajar Al-Aswad akhirnya kembali ke Makkah setelah 20 tahun.

\section{Wabah Kolera}

Wabah kolera yang terjadi di sepanjang abad ke-19 telah mengakibatkan ratusan ribu jamaah haji tewas. Penundaan haji sempat terjadi di sepanjang 18371846 M. Kolera kembali menyerang pada $1865 \mathrm{M}$ di wilayah yang disebut Hijaz termasuk Makkah di Arab Saudi. Sebuah konferensi internasional kemudian digelar di Konstatinopel, kini disebut Istanbul, untuk menghadapi kolera. Konferensi memutuskan pelabuhan yang menjadi tempat karantina sebelum jamaah melanjutkan perjalanan ibadah haji. Pelabuhan dibangun di wilayah seperti Sinai

\footnotetext{
${ }^{26} \mathrm{https}$ ///harianbangsa.net/lama-perjalanan-haji-di-masa-pandemi-corona-bisa-mencapaihampir-tiga-bulan

${ }^{27} \mathrm{https} / / /$ news.detik.com/berita/d-5038526/tak-hanya-haji-2020-rukun-islam-kelimapernah-40-kali-dibatalkan
} 
dan Hijaz untuk menekan risiko penyebaran penyakit. Antara tahun $1830 \mathrm{M}$ hingga $1930 \mathrm{M}$ tercatat sedikitnya ada 27 outbreak/kejadian luar biasa kolera pada jamaah haji di Makkah.

3. Wabah lainnya

Dikutip dari situs Arabia Weather, berikut wabah lain yang terjadi selama haji hingga harus ditunda, pada tahun 1814 ada The Plague yang menelan sekitar 8.000 orang meninggal di negara yang masuk dalam wilayah Hijaz karena wabah ini. Pada tahun 1831 terjadi Indian pandemi, Penyakit yang disebut indian pandemi ini membunuh $3 / 4$ jamaah haji yang ingin beribadah. Berdasarkan catatan pada 1246, penyakit tersebut dipercaya datang dari India dan mencapai outbreak/Kejadian Luar Biasa saat musim haji. Pada tahun 1837 terjadi Epidemic outbreaks saat musim haji dan epidemi ini terjadi hingga tahun 1840an.

4. Wabah typhoid dan meningitis

Outbreak typhoid pada 1895, yang disebut juga demam disentri, menyebar dari rombongan Madinah yang berlanjut dengan taraf lemah hingga Arafah. Penyakit ini tidak menyebar kemudian dan berakhir di Mina. Selain typhoid, pelaksanaan haji juga mencatat outbreak meningitis yang terjadi pada 1987. Penyakit yang parah dan sangat menular ini mengakibatkan sedikitnya 10.000 kasus infeksi. Akibat penyakit ini, jamaah haji dan umroh wajib suntik vaksin meningitis untuk mencegah tertular penyakit.

Pada dasarnya kejadian-kejadian wabah yang tidak terduga, menyebabkan perubahan besar bagi seluruh aspek kehidupan, salah satu dampak besarnya adalah ketidaknyamanan ibadah bagi umat Islam ini merupakan ujian paling buruk. Apalagi Ibadah Haji, merupakan Ibadah yang memerlukan keamanan negara dan kesinambungan antar negara. Dampak pembatalan ibadah haji ini juga sangat terasa bagi perekonomian, mulai dari pengusaha travel, kelompok bimbingan ibadah haji, pengadaan perlengkapan haji, pengusaha oleh-oleh haji, dan seterusnya.

Tatanan kehidupan baru yang merupakan keniscayaan memerlukan adaptasi yang tidak sebentar. Semua aspek kehidupan di tiap negara harus merubah tatanan yang biasa menjadi tidak biasa, contoh kecil seperti bersalaman sangat lazim dilakukan baik pada acara-acara formal maupun non-formal, akan tetapi saat dinyatakan dunia sedang pandemi COVID-19, maka bersalaman harus ditiadakan. Sehingga kelaziman baru mulai muncul secara perlahan. Hal inilah yang disebut dengan New Normal, dalam istilah kaidah fiqhiyah al-muhaafadhatu 'alalqadiimish shaalih, al-akhdzu bil-jadiidil ashlah (menjaga tradisi lama yang baik dan mengambil hal baru yang lebih baik). Kaidah inipun juga selalu menampilkan bahwa Hukum Islam selalu dinamis dan baik untuk semua umat manusia.

\section{- $\quad$ Penutup}

Hukum Islam selalu menjadi pusat perhatian dalam tiap kejadian di setiap waktu dan tempat, karena pemeluk Agama Islam yang taat dalam menjalankan agamanya, sehingga fatwa MUI maupun keputusan organisasi kemasyarakatan Islam selalu ditunggu responnya. Terpeliharanya agama (hifdhuddiin) menjadi tujuan utama bagi kehidupan Umat Islam, sehingga apapun yang diusahakan di dunia, selalu dikaitkan dengan kepentingan akhirat. Inilah yang menjadikan Hukum Islam selalu dinanti pemeluknya, bahkan seluruh masyarakat secara umum. 
Fleksibilitas Hukum Islam tercermin dalam percakapan Nabi Muhammad saw dengan Sahabat Muadz saat diutus menjadi Hakim di Yaman. Sahabat Mu'adz ditanyai tentang bagaimana ketika menemui masalah hukum, dia menjawab dengan perdoman Al-Qur'an, jika tidak ditemukan dalam Al-Qur'an, dicari dalam Sunnah Nabi saw dan ketika tidak juga ditemukan dalilnya dalam Sunnah, maka dengan ijtihad. Tentunya prosedur ijtihad ini telah disusun sistematis dalam kaidah fiqhiyah dari periode sahabat, tabi'iin, tabi'it tabi' in sampai sekarang.

Terjadinya Pandemi Covid-19 ini merupakan ujian bagi semua bangsa di dunia, sehingga memerlukan energi yang besar dalam menanganinya dan mengenyampingkan kepentingan lainnya. Dengan cara penularan yang cukup cepat dan membahayakan, tentunya banyak ibadah yang memerlukan kajian dalam praktiknya. Di sinilah fleksibilitas Hukum Islam semakin terlihat, dan kaidah fiqhiyah menjadi populer di kalangan umat Islam, terutama akademisi. Kajian tentang kebijakan juga dikenal dalam hukum Islam, tasharruful imam 'alarra' iyyah manutun bil mashlahah yang berarti kebijakan pemimpin harus berdasarkan kemaslahatan umat.

\section{DAFTAR PUSTAKA}

Abu Ishaq Al-Syathiby, Al-Muwafaqat fi Ushul al-Syari'ah, Jilid II, Beirut: Dar alMa'rifah.

Abdul Wahab Khalaaf, tt, Ilmu Ushul Fiqh, (Jakarta: Al-Majlisul A'la AlAindunisiyi Lida'watil Islamiyyati.

Ahmad al-Raisuni, 1991, Nadzariyat al-Maqashid 'Inda al-Syathibi, Dar alYaman, Rabath.

Ahmad Sukardja, Mujar ibnu Syarif, 2012, Tiga Kategori Hukum, Jakarta: Sinar Grafika.

Arif Fikri, Fleksibilitas Hukum Islam dalam Perubahan Sosial, http://ejournal.radenintan.ac.id

Asafri Jaya Bakri, 1996, Konsep Maqashid Syari'ah, Jakarta: Rajawali Pers.

Faried F. Saenong, dkk, 2020, Fikih Pandemi: Beribadah di masa wabah, Nuo Publishing, Jakarta.

Hasbi Ash-Shiddieqy, 1994, Pengantar Hukum Islam, Jakarta: Bulan Bintang.

------- 2001, Falsafah Hukum Islam, Semarang: Pustaka Rizki Putra.

Jasser Audah, Penerjemah Rasidin dan Ali Abd. Mun'im, 2015, Membumikan Hukum Islam melalui Maqashid Al-Syar'i. Mizan, Bandung.

Mahfud MD, 2011, Membangun Politik Hukum, Menegakkan Konstitusi, Jakarta: RajaGrafindo Persada

Moh. Dahlan, 2013, Paradigma Ushul Fiqh Multikultural Gus Dur, IAIN Bengkulu

Mukhtar Yahya, Fathurrahman, 1993, Dasar-dasar Pembinaan Hukum Fiqh Islami, Al-Ma'arif, Bandung.

Yayasan Penterjemah/Pentafsir Al-Qur'an, Al-Qur'an dan Terjemahnya, Madinah Munawwarah: Mujma' al-Malik Fahd Li Thiba'at al-Mushhaf Asy-Syarif 
http://ditjenpp.kemenkumham.go.id/htn-dan-puu/3000-peraturan-pemerintahpengganti-undang-undang-dari-masa-ke-masa.html

https://www.hukumonline.com/klinik/detail/ulasan/lt5188b1b2dfbd2/syaratsyarat-penetapan-perpu-oleh-presiden/

https://harianbangsa.net/lama-perjalanan-haji-di-masa-pandemi-corona-bisamencapai-hampir-tiga-bulan

https://news.detik.com/berita/d-5038526/tak-hanya-haji-2020-rukun-islamkelima-pernah-40-kali-dibatalkan

https://nasional.kompas.com/read/2020/06/02/10520421/pemerintah-batalkanpemberangkatan-jemaah-haji-2020. 